\title{
GYÁRTÁSKÖZI TEVÉKENYSÉGEK TELJESÍTMÉNYÉNEK VIZSGÁLATA
}

\author{
Erdei Edina
}

\begin{abstract}
Absztrakt: A termelésirányítási rendszerek ma informatikai aspektusokat is igényelnek, amikkel automatizálhatók, így könnyebben áttekinthetők a folyamatok. Kutatásom során három élelmiszergyártással foglalkozó vállalat 4 és fél évnyi adathalmazát és gépállományát elemeztem. Megállapítottam, hogy az ezen vállalatok a folyamatrendszerü gyártást részesítik előnyben. A késztermék előállításának egyes szakaszainak vizsgálatára az egyik legjobb időorientált módszert, a CPM elemzést alkalmaztam, melynek segítségével a tevékenységek időtartamára becsléseket készítettem. A doboz ábra elkészítése során kiszürtem az adathalmazból a kiugró adatokat, így pontosabb statisztikai becslést kaptam. Az átlag kiszámításával a teljes projekt várható befejezésére tettem javaslatot, ami a vevői rendelések szállítási dátumainak pontosabb meghatározására szolgál. Az eredmények összegzésével a vállalatok gyártási folyamatainak újratervezésére teszek javaslatot.
\end{abstract}

\begin{abstract}
Production management systems nowadays make IT aspects more automated so that processes can be easily overview. During my research, I have analyzed 4 and a half years of data set and machine stock of three food manufacturing companies. I have found that these companies prefer process-based production. One of the best time-oriented methods, the CPM analysis, was used to examine the stages of the production of the finished product, which made estimates for the duration of the activities. When drawing a box illustration, I extracted outbound data from the data set, so I got a more accurate statistical estimate. By calculating the average, I suggested the expected completion of the entire project, which is used to determine delivery dates for sales orders more accurately. By summarizing the results, I propose to redesign manufacturing processes in companies.
\end{abstract}

Kulcsszavak: folyamatrendszerü gyártás, időtartamok becslése, CPM elemzés, box-plot

Keywords: Process Manufacturing, Estimation of Time Duration, CPM Analysis, Box-Plot

\section{Bevezetés}

Mivel az élelmiszer-ellátás biztonságában kulcsszerepet tölt be az élelmiszer feldolgozása és továbbítása a fogyasztók felé, ezért kiemelt fontosságú az ágazat fejlesztése. Nemzeti érdek, hogy a fogyasztók megfelelő minőségü, egészséges és magyar élelmiszert vásároljanak, fellendítve ezzel a hazai vállalkozások kereskedelmét.

Az elektronikai eszközök folyamatos fejlődése lehetővé tette a könnyedén átprogramozható gépek kialakítását és bevezetését, így mára a gyártás teljes folyamata ezáltal hatékonyabbá vált, így a verseny is tovább fokozódott a vállalatok között. Minden gyártó vállalat egyik meghatározó pontja az automatizálás kialakítása, mellyel a hatékonyság és a hosszú távú költségcsökkentés fejlesztése a cél. A rendszerben zajló folyamatok célja olyan termékek előállítása, melynek következtében a vállalat nettó árbevétele növekszik.

A termelésirányítási rendszer információkat hoz létre müködése során, melyet célszerü vizsgálni ahhoz, hogy ezen adatok alapján fejlesszük a gyártási folyamatokat. A gyártási folyamatok tervezésekor és elemzésekor olyan eszközt érdemes alkalmazni, ami rögzíti az egyes folyamatokra szánt időtartamokat. A CPM elemzés kalkulál ezekkel az időtartamokkal, így elörejelzéseket tudunk készíteni az 
egyes folyamatok megvalósíthatóságára. A doboz ábra segítségével a modellben található kiugró adatok megállapíthatók és kiszürhetők, így a gyártási rekordokra alkalmazott átlag kiszámításával egy pontosabb becslést kaphatunk a projekt befejezésének várható időtartamára. Az adatok feldolgozásakor a vállalatok kapacitásának és az erőforrások optimális kihasználtságának meghatározása a fő cél, melynek folyamatos átgondolása és újratervezése a vállalatok rövid és hosszú távú célkitüzései közé tartozik.

Kutatásom során megállapítottam, hogy a gyártás pontos megvalósítására sokkal nagyobb energiát kell fordítani, hogy a vállalat versenyelőnyre tegyen szert a beszállító, kis- és nagykereskedő versenytársaival szemben.

\section{Szakirodalmi áttekintés}

\subsection{Kritikus út módszer}

Napjainkban egyre több kis- és középvállalat müködteti, felügyeli logisztikai, termelési, pénzügyi és egyéb tevékenységeit informatikai rendszerekkel, melyek az említett folyamatokat egységes keretben képesek kezelni (Oláh et al., 2017).

A hirtelen és folyamatosan változó üzleti világban és a magas költségek mellett a menedzsmentnek képesnek kell lennie arra, hogy megtervezze és hathatósan irányítsa a cég tevékenységeit. A menedzserek olyan eszközzel rendelkeznek, mellyel áttekinthetően tudják felépíteni a projekteket, ki tudják jelölni az egyes területek felelőseit, így előre kiszürhetik a késés lehetséges okait, amivel a költséges projektek idejéböl képesek megtakarítani (Erdei et al., 2018).

Ahhoz, hogy a gyártási folyamat zökkenőmentesen megvalósuljon fontos az alábbi részek akadálytalan lebonyolítása: beszerzés, raktározás, anyagmozgatás, technológia-tervezés, berendezések előkészítése, gyártás megszervezése, késztermékek elkészítésének az egyes fázisai, minőség-ellenőrzés stb. (Oláh et al., 2018).

A kritikus út módszert (CPM) 1957-ben J.E. Kelly fejlesztette ki a vegyi üzemet karbantartási szüneteinek tervezéséhez (Plotnick-O’Brien, 2009). A CPM módszer egy projekt időbeni ütemezését számolja ki és elemzi, mely grafikus ábrával jól szemléltethető. A CPM hálót teljes pontossággal felírjuk, a következő lépések átgondolása szükséges:

Adjuk meg a projektben lévő összes elvégzendő tevékenységet. Megjegyzendő, hogy míg a PERT elemzés esetében külön kezeljük a tevékenységeket és az eseményeket, addig a CPM esetében nem különböztetjük meg ezeket. Mivel ezek rokon értelemben használatosak a továbbiakban a CPM feladatokat tevékenységként fogjuk emlegetni (Woolf, 2012).

- Következő lépés a tevékenységek sorrendjének és kapcsolatának meghatározása. Mivel a CPM tevékenységorientált, ezért a nyilak csak a kapcsolatokat jelölik. Érdemes megemlíteni, hogy a háló szerkesztésénél a különbség a PERT és a CPM módszer között az, hogy az utóbbi esetén a 
csomópontok tevékenységeket jelölnek, nem eseményeket (ChanasZienlinski, 2001).

- Becsüljük meg minden egyes tevékenység időtartamát. A CPM eljárás nem tartalmaz semmilyen követelményt ezen értékek statisztikai becslésére, de valamilyen egyszerü statisztikai modell használatával eljuthatunk hozzá. Például vehetjük a kiválasztott időszak gyártási rekordjainak az átlagát (East, 2015).

- Tartalék nélkül határozzuk meg a kritikus utat. Ahhoz, hogy a tartalék időt megtudjuk határozni négy értéket kell kiszámolni minden eseményhez:

1. legkorábbi kezdési idő (early start, ES), ekkor kezdődhet meg legkorábban a tevékenység

2. legkorábbi befejezési idő (early finish, EF), ez a korai kezdési idő növelve a tevékenységhez szükséges idővel.

3. legkésőbbi kezdési idő (late start, LS), a projekt késleltetése nélkül ekkor kezdhetjük meg legkésőbb a tevékenységet

4. legkésőbbi befejezési idő (late finish, LF), ahhoz, hogy ne késsen a projekt, legkésőbb eddig kell elvégezni a tevékenységet (DeaconLingen, 2015).

Adjuk meg a tevékenységekhez tartozó tartalékidőket. Eseményenként képezhetjük a tartalékidőket LS-ES vagy LS- EF módon.

A globális áruáramlás iránya és a csomópontok növekedése a kereskedelmi hálózatokban jelentős hatással van a logisztikai központok fejlesztésére. A fogyasztói vásárlási szokások megváltozásai, az új ellátási láncok kialakulása befolyásolja az elosztási folyamatokat (Popp et al., 2018).

\subsection{Doboz ábra}

Az adatbázisban található szélsőséges adatok elhagyásával pontosabb statisztikai mutatószámokat kaphatunk. A kiugró adatok feltárására a doboz ábra (box-plot) szolgál, melynek lényege, hogy az interkvartilis terjedelem felső és alsó határát növeljük vagy csökkentsük (Vad et al., 2017). A dobozdiagram a változóknak a kvartilisek mentén történő grafikus ábrázolási módja. A dobozok egyes részei közötti távolságok az adatok szóródását, ferdeséget, valamint a kiugró értékeket jelzik (Boyle, 1986).

A doboz ábra segítségével grafikusan tudjuk szemléltetni a változók értékeinek a terjedelmét és elhelyezkedését. Továbbá megmutatja, hogy az adathalmaznak vannak-e kiugró pontjai, valamint az adatok szimmetriájáról és ferdeségéről is információt kaphatunk (Verde, 2014).

A doboz felső sarka a harmadik kvartilist, vagyis az adatok 75\%-át, az alsó sarka az első kvartilist, vagyis az adatok $25 \%$-át, a doboz középső része pedig az adatok $50 \%$-át tartalmazza. Tehát a minta terjedelme a harmadig kvartilis és az első kvartilis különbsége, vagyis az intervallum középső 50\%-a. A dobozban megtalálható vonal a mediánt jelzi. Ha a medián-vonal nincs egyenlő távolságra az alsó és felső saroktól, akkor az adatok aszimmetrikusak. A dobozból kiinduló vonalak végei a maximális és minimális értékeket jelzik (Rietz-Stannarius, 2017). 
A doboz ábra kétféle kiugró adatot reprezentál:

- enyhén kiugró értékek: ezek az értékek a belső határolóponton kívül, viszont a külsőhatároló ponton belül helyezkednek el, kör szimbólummal vannak jelölve. Ezek az értékek kívül esnek az interkvartilis terjedelem $* 1.5$ távolságon.

- extrém kiugró értékek: ezek az értékek a külső határolóponton kívül helyezkednek el, csillag szimbólummal vannak jelölve (Lem et al., 2017).

\section{Anyag és módszer}

A kutatásom során három élelmiszergyártó vállalatot vizsgáltam meg, melyek a hazai élelmiszeripari piac legkorszerübb gyártósoraival rendelkeznek. Mindhárom vállalat évi több tízezer tonnás termelökapacitás mellett odafigyel az innovatív termékfejlesztésre és az optimális ár-érték arányra. Fontosnak tartják a legyártott élelmiszerek biztonságát, minőségét és a környezettudatosság fontosságáról sem feledkeznek meg.

A gyártás során használt újszerü gépek nagy mennyiségben képesek automata módon kikeverni, megformázni, megtölteni, bepanírozni, kisütni, fagyasztani, mérni és becsomagolni az elkészült termékeket. A gyártás folyamatát képzett szakemberek irányítják és ellenőrzik. A termelő üzemekben saját laboratórium és szakhatósági kirendeltség is található az elkészült termékek minőségének ellenőrzéséhez.

A vállalatok évente többmillió ropogós falatot állítanak elő, melyekkel export és belföldi igényeket teljesítenek. Az elemzések szempontjából a három vállalatra vonatkozó legfontosabb információkat az 1. táblázat tartalmazza.

\section{1. táblázat: A vizsgált vállalatok legfontosabb adatai}

\begin{tabular}{lccc}
\hline Jellemző & „A” vállalat & „B” vállalat & „C” vállalat \\
\hline Vizsgált időszak kezdete & 2013.02 .01$. & 2013.02 .01$. & 2013.02 .01$. \\
Vizsgált időszak vége & 2017.10 .01$. & 2017.10 .01$. & 2017.10 .01$. \\
Gyártási rekordok száma (db) & 15855 & 16187 & 14898 \\
Vizsgált gyártási mennyiség (kg) & 1000 & 1000 & 1000 \\
Rekordok alsó kvartilise (perc) & 56.48 & 57.11 & 57.19 \\
Rekordok felső kvartilise (perc) & 58.49 & 59.10 & 59.10 \\
Interkvartilis*1,5 (perc) & 3.01 & 2.99 & 3.02 \\
Gyártás optimális intervalluma & $53.47-$ & $54.12-$ & $54.17-$ \\
(perc) & 61.50 & 62.09 & 62.12 \\
Kiugró adatok száma (db) & 103 & 122 & 102 \\
\hline
\end{tabular}

Forrás: saját kutatás, 2017

A három vállalat elemzése 4 és fél évnyi adathalmazból készült, mely során egy termék legyártásának a várható időtartamát vizsgáltam meg. A fő cél a gyártási idők mélyebb szintü elemzése volt, mely során a gyártás befejezésének várható idejét becsültem meg. A kalkulációk a kapacitások kihasználtságának megtervezésén felül a vevői igények pontosabb kiszolgálását teszik lehetővé. 
Kutatásom során a CPM elemzést alkalmaztam, mely az egyik legjobb időorientált módszer, így a következő részekben annak eredményeit mutatom be. Az elemzés következtében megállapíthatóvá vált az eszközökön történő mennyiségek elkészülésének gyártási ideje, így a előrejelzéseket készítettem a gyártási idők befejezésére. Fontos, hogy az adathalmazban található kiugró adatokat kivettem a modellből, ezáltal a gyártási rekordokból történtő átlag kiszámításával pontosabb becslést kaptam.

\section{Eredmények}

\subsection{Gyártás folyamatrendszerü folyamata}

Az élelmiszer iparágra szakosodott vállalatoknál a legelterjedtebb megoldás a folyamatrendszerü gyártás, hiszen az anyagutak csökkentése lényeges időbeli nyereséget jelent a vállalatok számára.

A gyártás alapanyag ellátásának folyamata a megrendelésektől és a beszállítóktól függ, akiket késedelmes szállítás esetén kötbér fizetésre kötelezhetnek. Fontos, hogy a vállalatok megbízható szállítókkal tartsák a kapcsolatot, ezenkívül kiváló alapanyagok, optimális szerszámokok és emberi erőforrások álljanak a rendelkezésükre. Nélkülözhetetlen a megérkezett alapanyagok megfelelő raktározása, mivel a gyártani kívánt termékek minőségét az alapanyagok tárolása is jelentősen befolyásolja. Költséget takaríthatunk meg, ha probléma van a feldolgozandó alapanyaggal és azt annak feldolgozása előtt kiszürjük.

A három vállalat egyik késztermékének elöállításának fö folyamatát a Microsoft Project program által készített 1 . ábra szemlélteti. A feltüntetett időtartamok 1 tonna késztermék elkészítésére vonatkoznak.

\section{1. ábra: Élelmiszergyártás folyamata}

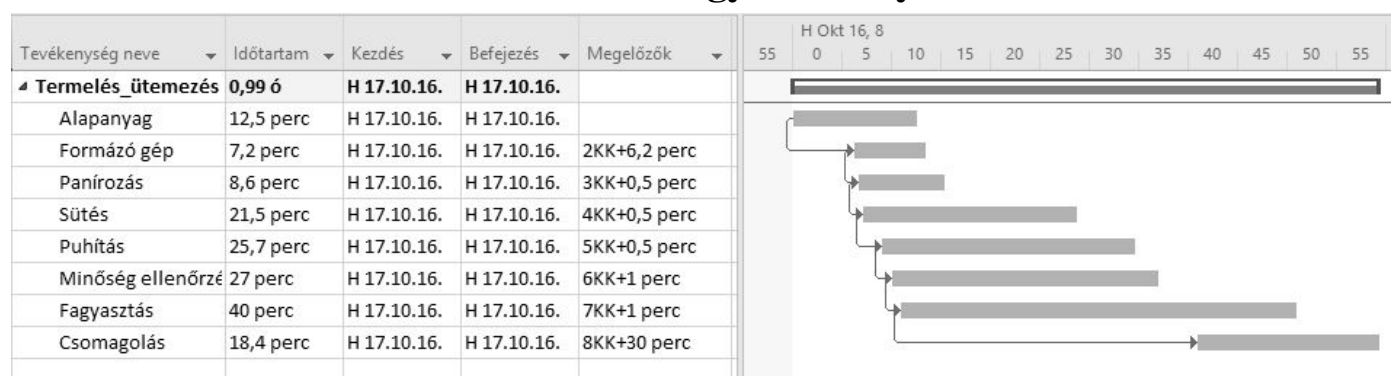

Forrás: A szerző saját szerkesztése. (2017)

A feldolgozás az alapanyagok kicsomagolásával kezdődik, ahol a „B” vállalat a munkaállomásai segítségével az 1 tonna készterméket 12.5 perc alatt felaprítja és folyékonnyá teszi. Az üzemben minden gépnek van egy vezérlőegysége, amin beállítható, hogy hány percig és milyen fordulatszámon dolgozzon a berendezés az alapanyagokkal és félkész termékekkel. Az alapanyag szabályszerü alakját 7.5 perc alatt egy formázó gép elkészíti, melynek feje - attól függően, hogy milyen alakú késztermékeket szeretnének elkészíteni - lecserélhető. A formázás egy futószalag kiinduló állomása, mely után a termékek bepanírozása, füszerezése következik. Ezt 
követően a futószalagon lévő félkész termékeket olajban kisütik, majd gőzben megpuhítják, aminek eredményeképpen a késztermékek elkészülnek. A puhításra jóval több időt kell szánni, mivel a külső jellemzők mellett a legfontosabb, a késztermékek belső tulajdonságainak magas minősége. A minőségellenőrzés a gyártás legfontosabb pontja, ez jelenti az utolsó kaput a vevők előtt, ahol még észrevehetik a hibákat. A „B” vállalat esetén a gyártási folyamat ezen része körülbelül 27 percet vesz igénybe, amikoris a termékek főbb jellemzőjének (szín, íz, forma) vizsgálata történik. Bármilyen hiba felmerülésekor a késztermékek automatikusan selejtezésre kerülnek. A minőségellenőrzés után a késztermékek lefagyasztása történik. A fagyasztó hömérsékletét a késztermék állagától függően határozzák meg, mely akár $-70^{\circ} \mathrm{C}$ körüli is lehet. A megvizsgált vállalatok esetén egy késztermék körülbelül 30-40 percet tölt a fagyasztóban, mielőtt azt becsomagolják. A csomagoló gép rekeszeiben a késztermékek helyezkednek el. Minden egyes rekesz súlya maximum 10 grammal térhet el az elöírásokban megfogalmazottaktól. Amennyiben a súly nem felelt meg a követelményeknek, akkor annak tartalma egy úgynevezett selejt dobozba került. A csomagoló gép egyetlen vágással és ragasztással becsomagolja az elkészült terméket. Az utolsó részfolyamat a „B” vállalatnál 18.4 percet vesz igénybe 1 tonna termék esetén (körülbelül 2200 csomag). A dolgozók a csomagokat dobozokba helyezik, majd azt egy fagyos raktárba viszik, ahonnan állításuk szerint 1-1.5 héten belül a késztermék eladásra kerül.

\subsection{CPM módszer eredménye}

A vállalatoknak egyre fontosabbá vált, hogy az összetett, bonyolult logikai és időrendi kapcsolatban álló tevékenységeket a lehető leggyorsabban, valamint minél hatékonyabban tudják elvégezni. Így a CPM módszer végső célja a folyamatok áttekintése után az egyes tevékenységek és a projekt várható befejezésének időtartamának a kiszámítása.

A gyártási rekordokban található szélsőséges adatok megtartásával kissé pontatlan eredményhez juthatunk, így azok elhagyásával megbízhatóbb statisztikai mutatószámokat kapunk. Ezen kiugró adatok feltárására alkalmas a doboz-ábra. A doboz ábra segítségével az egyes vállalatok gyártási rekordjait elemezve meghatározható az interkvartilis terjedelem, mely az adatok középső 50\%-át fedi le (2. ábra). 
2. ábra: A vállalatok (,,A”, „,B”, „C”) doboz ábrái

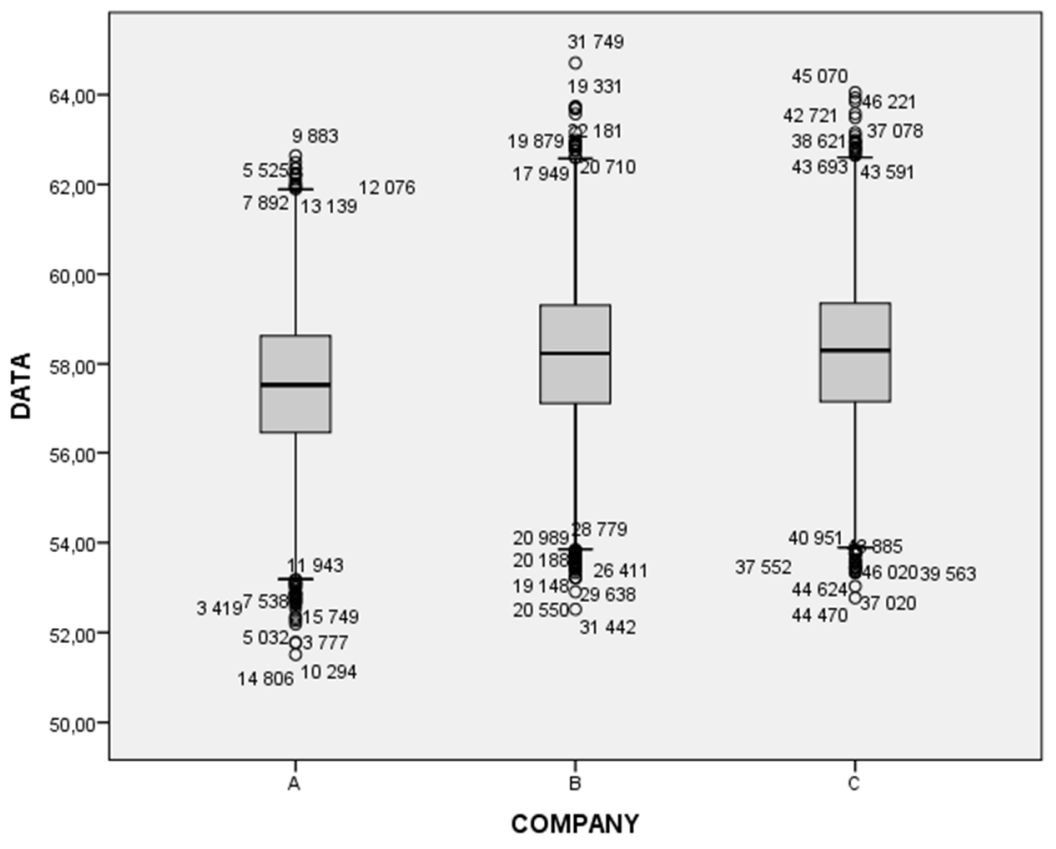

Forrás: A szerző saját szerkesztése. (2017)

A doboz ábra alapján megállapítható, hogy az „A” vállalat gyártásának optimális intervalluma 53.47 és 61.50 perc között van, így az ezen intervallumon kívül eső rekordokat eltávolítottam az adathalmazból. A kvartilisek kiszámítását követően az alsó kvartilisből az interkvartilis terjedelem másfélszeresét kivonva az optimális intervallum alsó értékét kapjuk eredményül.

A „B” vállalat adatbázisában található a legtöbb kiugró adat, mindösszesen 122 db. Az eredményekből kiderül, hogy a 3 vállalat nagyságrendileg hasonló mennyiségü kiugró adattal rendelkezik, melyek a gyártás során előforduló hibák miatt keletkezhettek.

Mindhárom vállalathoz tartozó doboz ábrán a medián-vonal megközelítőleg egyenlő távolságra van az alsó és a felső saroktól, mely az adatok eloszlásának szimmetrikusságára utal. A vállalatok kiugró értékeinek eltávolítására trimmelélést alkalmaztam, melynek célja a doboz ábra segítségével megállapított, a gyártási időre vonatkozó optimális intervallumon kívül eső elemek elhagyása.

A kiszürt adatok megfelelő szemléltetésére hisztogramot alkalmaztam, mely az adatok eloszlását mutatja meg. Az „A” vállalat gyártási rekordjaiból készült hisztogram a 3. ábrán látható. 


\section{3. ábra: $\mathbf{A z}, \mathbf{A}$ ” vállalat gyártási rekordjainak hisztogramja}

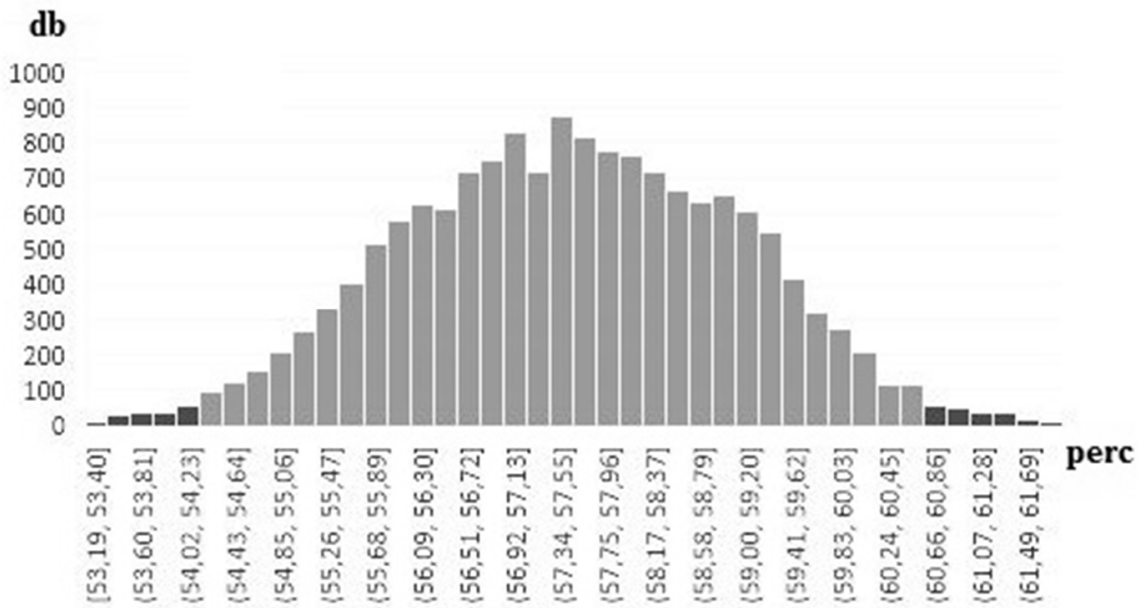

Forrás: A szerző saját szerkesztése. (2017)

Megfigyelhetö, hogy a modellből a sötétebb színnel jelölt részeket érdemes kivennünk, hiszen azok előfordulása jelentősen befolyásolja az átlagszámításon alapuló becslés eredményét. A kiszüréssel egy pontosabb becslést tudunk kapni a projekt várható befejezésének időtartamára. A kiugró adatokat tartalmazó és nem tartalmazó adatbázisokra kapott leíró statisztikákat az alábbi 4. ábra tartalmazza.

\section{4. ábra: A vizsgált vállalatok legfontosabb adatai}

\begin{tabular}{|l|c|r|r|r|r|}
\hline & \multicolumn{1}{|c|}{ N } & Minimum & Maximum & \multicolumn{1}{c|}{ Mean } & Std. Deviation \\
\hline A_unfiltered & 15855 & 51,20 & 62,82 & 57,7903 & 1,81210 \\
A_filtered & 15752 & 51,51 & 62,64 & 57,4781 & 1,47971 \\
B_unfiltered & 16187 & 52,12 & 65,80 & 58,4974 & 1,85761 \\
B_filtered & 16065 & 52,52 & 64,71 & 58,0948 & 1,48725 \\
C_unfiltered & 14898 & 51,65 & 65,34 & 58,7339 & 2,01706 \\
C_filtered & 14796 & 52,77 & 64,05 & 58,1971 & 1,49597 \\
\hline
\end{tabular}

Forrás: A szerző saját szerkesztése. (2017)

A három vállalatra vonatkozó szürt és szüretlen adatokból elmondható, hogy a kiugró adatok eltávolítása jelentősen befolyásolta a becslés végeredményét. A „C” vállalat esetén például 1.29 perccel eltér a két adatbázis maximum értéke, ami több, mint 0.5 perccel módosítja az átlagot. Ez az eltérés a munkaállomás hiba miatti megállásából következhetett, ezért fontos a vállalat folyamatainak felülvizsgálata és a munkagépek által bekövetkezett hibák csökkentése.

Fontos, hogy az adathalmazra nem érdemes súlyozott átlagszámítást alkalmazni, hiszen ekkor egyes értékeket nagyobb súllyal veszünk figyelembe, mely jelentősen módosíthatja a becsült gyártási időt, így egy torzított becslést kapunk, mely kevésbé közelít a várható gyártási időhöz. 


\section{Következtetések és javaslatok}

A gyártási folyamat zökkenőmentes megvalósításához fontos az alábbi részek akadálytalan lebonyolítása: technológia-tervezés, beszerzés, raktározás, anyagmozgatás, gyártó berendezések előkészítése, gyártási folyamat megtervezése, késztermékek elkészítése és a minőségellenőrzés.

A gyártóberendezések elhelyezkedésétől függ az élelmiszerek útja, amely befolyásolja a gyártási rendszer rugalmasságát, az idő- és költségigényeket, az anyagmozgatást, és a gyártás egyes szakaszainak az átfutási idejét. Megállapításaim szerint, az élelmiszer iparágban tevékenykedő vállalatok a folyamatrendszerü gyártást előnyben részesítik a csoportrendszerü gyártással szemben, hiszen a futószalagos megoldással az egyes müveletek közötti átfutási idő lecsökken, aminek köszönhetően a termelés volumene megnő. Fontos, hogy a vállalatok odafigyeljenek az automatizáció optimális kialakítására, mellyel - a termékek gyors és hatékony elóállításával - a versenyelőny megszerzése és fenntartása a cél.

A vállalatok érdeke nemcsak az, hogy a vevői igényeknek alapján kiszámított termelési mennyiséget határidőn belül legyártsák, hanem az is, hogy a fogyasztók kiváló minőségü élelmiszert vásároljanak.

Mivel a termelésirányítási rendszer működése során információt bocsált ki, ezért a munkafolyamatok közben is folyamatosan felügyelhető a félkész- és késztermékek minősége. Az élelmiszerek esetén valamennyi elkészült darabon minőségellenőrzést kell végrehajtani. A vizsgálat minél pontosabb, annál nagyobb költségráfordítást jelent.

Kutatásom során a CPM módszer segítségével becsléseket készítettem a tevékenységek időtartamára a három vállalat adatbázisán. Doboz ábra segítségével a gyártási rekordok között megtalálható kiugró adatokat kiszűrtem a modellből, így az átlagszámítás során pontosabb adathoz jutottam. A különböző számítások alapján a projekt befejezésének becsült időtartama 58 perc körüli, ami kimondja, hogy egy élelmiszert gyártó vállalat 1 tonnányi mennyiséget egy korábban definiált termékből körülbelül 58 perc alatt képes legyártani. Ez a következtetés és a gyártási idő pontosabb meghatározását segítik elö, így könnyebbé válik a szállítási dátumok kiszámítása is.

Továbbá megállapítottam, hogy az „A” vállalat kevesebb idő alatt végzi el az 1 tonna késztermék legyártását, mint a másik két vállalat, melynek oka jól kidolgozott gyártási tervek, modernebb gépek és ütemezések használata. A „C" vállalatnak újra kellene gondolni a folyamatok újratervezését, mivel 1-2 perc is óriási gyártási mennyiség kiesést eredményez.

Minden vállalat szeretné az általa előállított termékek minőségét megtartani és fejleszteni, ami a gyártás pontos kidolgozása esetén lehetséges. Az élelmiszer feldolgozása és továbbítása a fogyasztók felé az élelmiszer-ellátás biztonságában kulcsszerepet tölt be, ezért alapvető fontosságú az ágazat kiemelt fejlesztése.

\footnotetext{
MIIISTTRRIUMA AZ EMBERI ERŐFORRÁSOK MINISZTÉRIUMA ÚNKP-18-3 KÓDSZÁMÚ ÚJ NEMZETI KIVÁLÓSÁG PROGRAMJÁNAK TÁMOGATÁSÁVAL KÉSZÜLT"
} 


\section{Irodalomjegyzék}

Boyle, C. (1986): Display the Data: Box-Plots. In: Mastering Statistics with your Microcomputer. Macmillan Master Series. Palgrave, London.

Chanas, S., Zienlinski. P. (2001): Critical Path Analysis in the network with fuzzy activity times. Fuzzy Sets and Systems, 122 (2): 195-204.

Deacon, H., Lingen, Van der E. (2015): The use of the critical path and critical chain methods in the South African construction industry. Journal for the Physical and Development Sciences, 22 (1): 73-95.

East, W. (2015): Critical Path Method (CPM) Tutor for Construction Planning and Scheduling. Series: P/L Custom Scoring Survey. McGraw-Hill Education.

Erdei E., Popp J, Oláh J. (2018): Comparison of time-oriented methods to check manufacturing activities and an examination of their efficiency. LogForum, 14 (3): 371-386

Lem, S., Onghena. P., Verschaffel, L., Van Dooren, W. (2017): The power of refutational text: changing intuitions about the interpretation of box plots. European Journal of Psychology of Education, 32 (4): 537-550.

Oláh J., Erdei E., Popp J. (2017): Értékesítési adatok klaszteranalízise és előrejelzések készítése SAP HANA platformon. Controller Info, 5 (1): 12-17.

Oláh J., Zéman Z., Balogh I., Popp J. (2018): Future challenges and areas of development for supply chain management. LogForum, 14 (1): 127-138.

Plotnick, F. L., O’Brien, J. J. (2009): CPM in Construction Management, Seventh Edition. McGraw Hill.

Popp J., Oláh J., Farkas Fekete M., Lakner Z., Máté D. (2018): The Relationship Between Prices of Various Metals, Oil and Scarcity. Energies, 11 (9): 1-19.

Rietz, F., Stannarius, R. (2017): Beads in a Rotating Box. In:. Müller, S. C., Plath, P. J., Radons, G., Fuchs, A. (szerk.): Complexity and Synergetics. 51-60.

Vad, V., Cedrim, D., Busch, W., Filzmoser, P., Viola, I. (2017): Generalized box-plot for root growth ensembles. BMC Bioinformatics, 18 (Suppl 2): 65.

Verde, R., Irpino, A., Rivoli, L. (2014): A Box-Plot and Outliers Detection Proposal for Histogram Data: New Tools for Data Stream Analysis. In: Vicari, D., Okada, A., Ragozini, G., Weihs, C. (szerk.): Analysis and Modeling of Complex Data in Behavioral and Social Sciences. 283-291.

Woolf, M. B. (2012): CPM Mechanics: The Critical Path Method of Modeling Project Execution Strategy. ICS-Publications. 